\title{
Simplified Measurement on the Impact of Radiation by Mobiles
}

\author{
P.A. Kumar, Phani Kumar.Ch.R
}

\begin{abstract}
Mobile phone has become part of the human life. Specific Absorption is a measurement for the amount of Electromagnetic energy that has been absorbed by human tissue ,. Electromagnetic Radiation associated with Mobile Phones is always as an issue that has to be addressed for human safety, Particularly for children. More focus has been paid to induced SAR in the human head when exposed to EM Waves emitted from mobile Phone Antenna, but while using mobile phone the user gets exposed to a dangerous electromagnetic Radiations. ICNIRP Prescribed some guidelines for EM Exposure Level for Public. The Present paper is discuss the SAR Values of different Mobile Phones, Measured How much People are Aware of SAR Values are given as a survey. The study is compromised individuals that visited in the survey site.The awareness is assessed using structured questions and it was recorded to measure the awareness.
\end{abstract}

Keywords: EM exposure, ICNIRP,SAR, Socio-Demographic

\section{INTRODUCTION}

EMF effect on human body mainly depends on Frequency of EMF and Magnitude..Electronic gadgets are perceived as a fundamental components of every day life, The Portable terminal devices become the Part and parcel of Present Scinario, and the uses of those are expanding step by step. Electro Magnetic Field Radiated by antennas of Mobile Phone strongly Interact With Human Head and other Human body parts. The Most Immediate effect of Electromagnetic Radiation is Increasing of Temperature of Tissues. The Electromagnetic energy Absorbed by the tissue Converts into heat in the human body. When Electromagnetic energy hit the material generates heat and heating capacity is depends on energy of electromagnetic wave. in some Applications needs more antennas situated in a phone, it causes increasing of thermal heating is still challenging problem for safety and study of these unwanted health effects is most important topic in Recent Days. Although This Problem is Being Investigated for a longer time, still there is most Harmful Difficulty in the field. Specific Absorption Rate(SAR) and Power Density which treats to be suitable Parameter for Calculating the degree of absorption...The Distribution of RF Fields in in equal structures like human head is complicate and difficult to predict, because it is depends on number of factors Like Near

Revised Manuscript Received on December 13, 2019.

* Correspondence Author Technology,Visakhapatnam,A.P

Email Id:ashok.pentaece@gmail.com

Raghavendra Phani Kumar.Ch,Assistant Professor,GITAM Deemed

to be University,Visakhapatnam,A.P

Email id:rphanikumar.chintalapudi@gitam.edu
Majority of The Research focused on Variation of the

P.A.Kumar *, Assistant Professor,Avanthi Institute of Engineering \&

field or Far Field and Frequency of incident Fields and Dielectric Properties of the body

\section{SAR}

The Fields Penetrate short distances into the body at Radio Frequencies. The Energy of field is absorbed and transferred into the molecules, temperature rise arises due to fiction o molecules. Generally it is opposite to Power Density (PD), it is used Measure the EMF Exposure in FAR Field Region.. .especially body having highest water content results in high SAR Values.. The Reduction of SAR is an essential issue for the mobile phones and majority of research work is going on this aspect.

$\sigma=$ Conductivity of tissue

$$
\mathrm{SAR}=\frac{\sigma|E|^{2}}{\rho}
$$

E $=$ RMS Value of Electric Field

$\rho=$ Density of tissue

Specific Absorption Rate Limits for Different Countries

Table I: SAR Limits

\begin{tabular}{|c|c|}
\hline Country & SAR Limit $(\mathrm{W} / \mathrm{Kg})$ \\
\hline Japan & $2.0(10$ gram $)$ \\
\hline Korea & $1.6(1$ gram $)$ \\
\hline USA \& Canada & $1.6(1$ gram $)$ \\
\hline EU & $2.0(10$ gram $)$ \\
\hline India & $1.6(1$ gram $)$ \\
\hline & \\
\hline
\end{tabular}

A. Mathematical Expression For SAR\& Temperature Rise in Tissue

$\mathrm{SAR}=\frac{\text { Power Absorbed by human tissue }}{\text { Mass of the Tissue }}$

Power absorbed by human tissue $(\mathrm{P})=$ Voltage $(\mathrm{V}) *$ Current (I)

$$
\begin{gathered}
\text { Current density }(\mathrm{J})=\frac{\text { Current }(I)}{\text { Area }(A)} \\
\text { Current }(\mathrm{I})=\text { Current Density }(\mathrm{J}) * \text { Area }(\mathrm{A}) \\
\text { Electric Field }=\frac{\text { Voltage }}{\text { Lengt } h}=\frac{V}{L} \\
\text { Voltage }(\mathrm{V})=\text { Electric Field }(\mathrm{E}) * \text { Length }(\mathrm{L}) \\
\text { Power Absorbed by tissue }(\mathrm{P})=\mathrm{V} * \mathrm{I} \\
\mathrm{P}=\mathrm{E} * \mathrm{~L} * \mathrm{~J} * \mathrm{~A} \\
\text { Rearranging the equation } \\
\mathrm{P}=\mathrm{J} * \mathrm{E} * \mathrm{~L} * \mathrm{~A}
\end{gathered}
$$

(Where J=Current Density, E= Electric Field, L=Length, $\mathrm{A}=$ Area)

Where Current Density $(\mathbf{J})=$ Conductivity $(\sigma)^{*}$ Electric Field (E)

$$
\begin{gathered}
\mathrm{J}=\sigma^{*} \mathrm{E} \\
\mathrm{P}=\sigma \mathrm{EELA}
\end{gathered}
$$


Substituted in equation (1)

$$
=E^{2} \mathrm{LA} \sigma
$$

$$
\mathrm{SAR}=\frac{E^{2} \sigma}{\rho}(\mathrm{W} / \mathrm{Kg})
$$

Power Per Unit Area(S) (poynting Theoram) = Electric Field(E)*Magnetic Intensity $(\mathrm{H})$

$$
\mathrm{S}=\mathrm{E}^{*} \mathrm{H}
$$

Intrinsic impedance $(\eta)=\frac{\text { Electric Field }(E)}{\text { Magnetic intensity }(H)}$

$$
\eta=\frac{E}{H} \text { (units: ohms) }
$$

$\mathrm{H}=\frac{E}{\eta}$ (units: amperes/meter)

$$
\begin{array}{r}
\mathrm{S}=\mathrm{E} * \frac{E}{\eta} \\
\mathrm{SAR}=\frac{S \eta \sigma}{\rho}
\end{array}
$$

Temperature Change $(\Delta \mathrm{T})=\frac{S A R * \Delta t}{C}$

$\Delta \mathrm{T}=$ Temperature Change of tissue

$\Delta \mathrm{t}=$ Exposure of Radiations(duration)

$\mathrm{C}=$ Tissue specific heat

Clearly SAR is Directly Proportional to $\frac{\Delta T}{\Delta t}$

\section{SAR VALUES FOR SOME MObILE MANUfaCtURES (LTE)}

Electrical Conductivity of human tissue is increases when frequency is increased, Mobile Terminal Engineers are trying hard to meet the safety limit for head SAR at high frequencies The SAR Value Measured at head having highest absorption Rates. The Long Term Evolution (LTE) offers High data Rates when Compared to GSM 900 and $1800 \mathrm{MHz}$,

Table II: SAR Values for Different Mobile Manufacturers

\begin{tabular}{|l|l|c|c|}
\hline S. No & \multicolumn{1}{|c|}{$\begin{array}{c}\text { Mobile Manufacturer } \\
\text { Name }\end{array}$} & $\begin{array}{c}\text { SAR } \\
\text { (Head) } \\
(\mathrm{W} / \mathrm{Kg})\end{array}$ & $\begin{array}{c}\text { SAR } \\
\text { (Body) } \\
(\mathrm{W} / \mathrm{Kg})\end{array}$ \\
\hline 1. & OPPO Realme1 & 1.4 & 0.909 \\
\hline 2. & Redmi Note4 & 0.375 & -- \\
\hline 3. & MI A1 & 1.26 & -- \\
\hline 4. & Cool Pad Mega & 0.574 & 0.982 \\
\hline 5. & Samsung Galaxy & 0.780 & -- \\
\hline 6. & Samsung J8 & 0.697 & - \\
\hline 7. & Oppo & 0.984 & 0.433 \\
\hline 8. & Redmi Note7 Pro & 0.962 & 0.838 \\
\hline 9. & MI Note5 Pro & 1.188 & 0.334 \\
\hline 10. & Samsung M20 & 0.273 & -- \\
\hline 11. & VIVO V11(PRO) & 1.2588 & 0.482 \\
\hline 12. & MI Max & 0.838 & -- \\
\hline 13. & Samsung J7 Nxt & 0.610 & -- \\
\hline 14. & VIVO Y95 & 1.09 & 0.32 \\
\hline 15. & Samsung J7 & 0.551 & -- \\
\hline
\end{tabular}

\begin{tabular}{|c|l|c|c|}
\hline 16. & OPPO F9 Pro & 1.312 & 0.829 \\
\hline 17. & Asus Lite & 0.468 & 0.981 \\
\hline 18. & $\begin{array}{l}\text { Asus Zen Phone } \\
\text { Max }\end{array}$ & 0.454 & 0.274 \\
\hline 19. & VIVO 1606 & 0.496 & 0.786 \\
\hline 20. & Samsung J3 & 0.903 & -- \\
\hline 21. & MI Note 5 & 0.751 & -- \\
\hline 22. & Oppo Realme & 1.132 & 0.569 \\
\hline 23. & Honor 9 & 0.42 & -- \\
\hline 24. & Honor Play & 1.10 & -- \\
\hline
\end{tabular}

\begin{tabular}{|c|l|c|c|}
\hline 25. & Vivo y69 & 1.212 & 1.31 \\
\hline 26. & Redmi 4A & 0.596 & -- \\
\hline 27. & Moto E4 & 0.500 & 0.914 \\
\hline 28. & Realme3 & 0.976 & 0.261 \\
\hline 29. & Oneplus & 1.20 & 0.68 \\
\hline 30. & Honor 7 & 1.23 & -- \\
\hline
\end{tabular}

Total number of Mobiles Verified for $\mathrm{SAR}=30$

Table III: Analysis of the Head SAR Range (Graph)

\begin{tabular}{|c|c|c|c|}
\hline S. No & $\begin{array}{c}\text { SAR } \\
\text { Range(W/Kg) } \\
\text { for Head }\end{array}$ & $\begin{array}{c}\text { Total No. of } \\
\text { Mobiles }\end{array}$ & Percentage \\
\hline 1 & $0-0.4$ & 06 & $20 \%$ \\
\hline 2 & $0.5-0.9$ & 13 & $43.33 \%$ \\
\hline 3 & $1-1.6$ & 11 & $36.66 \%$ \\
\hline
\end{tabular}

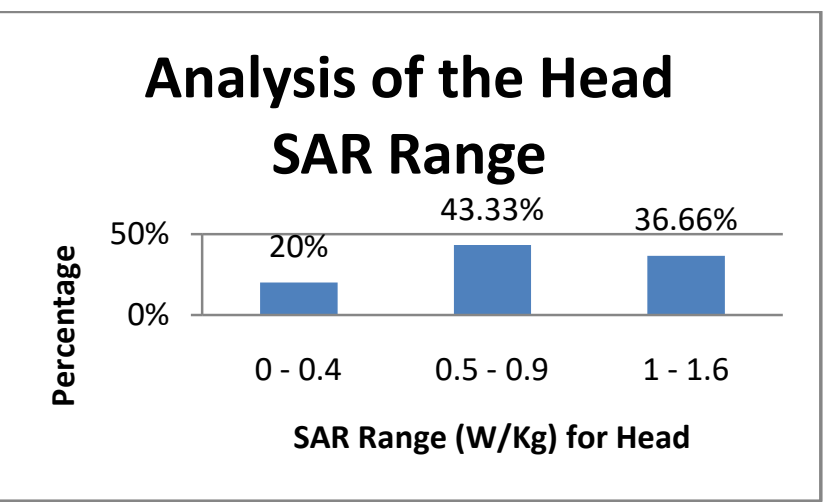

Fig. 1. Analysis of the Head SAR Range

\section{RESUlts \& Discussions}

\section{A. Socio-Demographic Profile:}

Total Number of samples taken is 200 in the period of 3 Months. Maximum range of age group 17-50 years. Majority Respondents are in the age group 20-34 years is 148 members(74\%),Male Respondents is 138 members(69\%) and

\begin{tabular}{|c|c|c|}
\hline Demographics & Total & $\%$ \\
\hline Gender - Male & 138 & $69 \%$ \\
\hline Female & 62 & $31 \%$ \\
\hline \multicolumn{3}{|l|}{ Occupation } \\
\hline Students & 115 & $57.5 \%$ \\
\hline $\begin{array}{l}\text { Service } \\
\text { (Employees) }\end{array}$ & 85 & $42.5 \%$ \\
\hline \multicolumn{3}{|l|}{ Education } \\
\hline Under Graduation & 95 & $47.5 \%$ \\
\hline $\begin{array}{l}\text { Post Graduates } \\
\text { (Including Employees } \\
\text { and Students) }\end{array}$ & 105 & $52.5 \%$ \\
\hline \multicolumn{3}{|l|}{ Age } \\
\hline $\begin{array}{l}18-24 \\
\text { (students including } \\
\text { Graduation and Post } \\
\text { Graduation) }\end{array}$ & 62 & $31 \%$ \\
\hline $25-29$ & 32 & $16 \%$ \\
\hline $30-34$ & 54 & $27 \%$ \\
\hline $35-39$ & 26 & $13 \%$ \\
\hline $\begin{array}{l}\text { Published By: } \\
\text { Blue Eyes Intelliger } \\
\text { \& Sciences Publica }\end{array}$ & & ition \\
\hline
\end{tabular}
female Respondents are 62(31\%),Most of the Respondents are students 115 members $(57.5 \%)$ employees were $85(42.5 \%)$ and graduating students are $95(47.5 \%)$ and post graduates are $105(52.5 \%)$.

Table IV: Demographics of Respondents 


\begin{tabular}{|l|c|c|}
\hline $40-44$ & 15 & $7.5 \%$ \\
\hline $45-50$ & 09 & $4.5 \%$ \\
\hline Greater than 55 & 02 & $1 \%$ \\
\hline
\end{tabular}

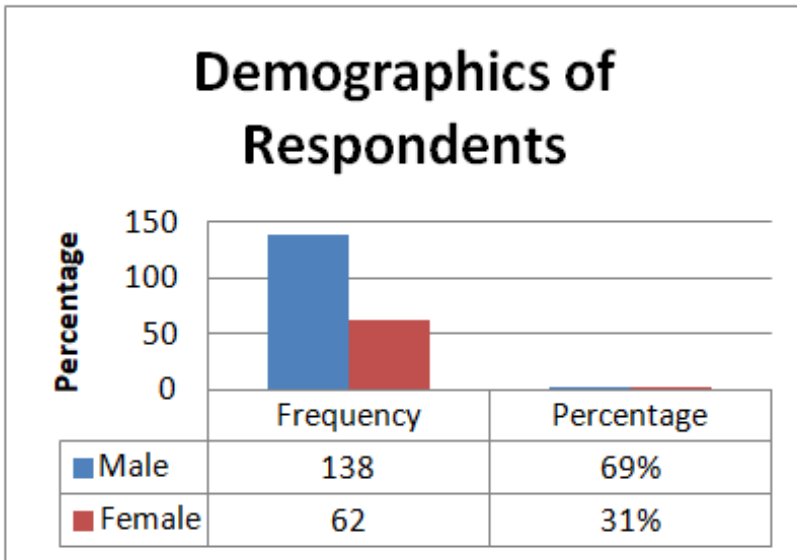

Fig. 2. Analysis of the Head SARR Range

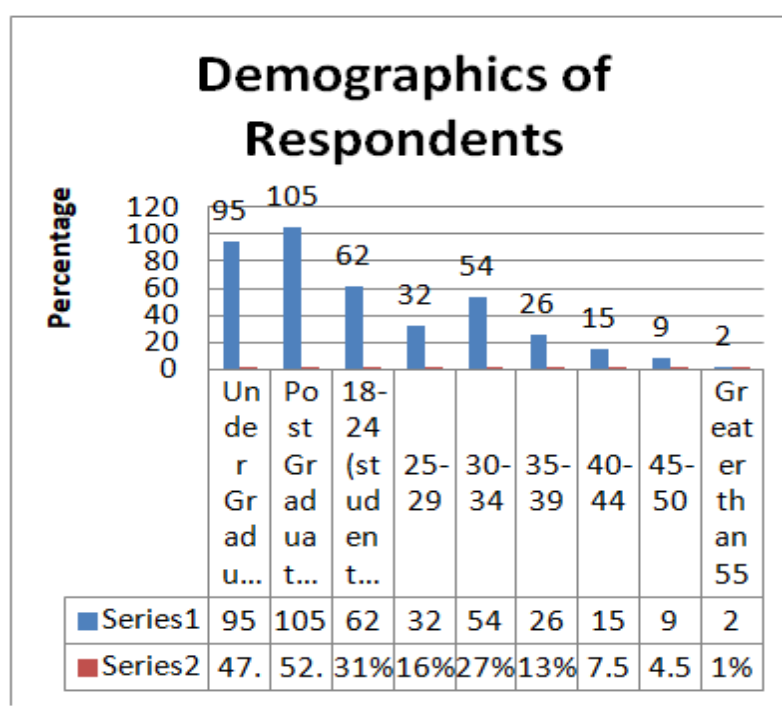

Fig. 3: Analysis of the Head SAR Range

\section{B. Awareness of SAR Value:}

Out of 200 samples only 30 members $(15 \%)$ aware about SAR Value., out of which 14(total 85) (16\%) members from service and 16(total 115) from students category(13\%).Males are Comparatively aware than females as only $14 \%$ of mobile users are aware of SAR value, and safety limit for Mobile as per ICNIRP Guidelines. Generally in India People unaware of Mobile Phones hazards, SAR Value is the most important Parameter to be considered in buying a mobile Phone

Table V: Awareness of SAR Level

\begin{tabular}{|c|c|c|c|c|}
\hline \multirow{3}{*}{\multicolumn{2}{|c|}{ Demographics }} & \multicolumn{2}{|c|}{ Awareness } & \multirow{4}{*}{$\begin{array}{c}\text { Percentage } \\
15 \%\end{array}$} \\
\hline & & \multirow{3}{*}{$\frac{\text { Aware }}{21}$} & & \\
\hline & & & \multirow{2}{*}{$\begin{array}{l}\text { unaware } \\
117\end{array}$} & \\
\hline Male & (138) & & & \\
\hline Female & (62) & 09 & 53 & $14 \%$ \\
\hline \multicolumn{5}{|c|}{ Education } \\
\hline \multirow{2}{*}{\multicolumn{2}{|c|}{ Graduation(95) }} & 10 & 85 & \multirow[t]{2}{*}{$10 \%$} \\
\hline & & \multicolumn{2}{|c|}{ Male-8, Female-02 } & \\
\hline \multirow{2}{*}{\multicolumn{2}{|c|}{$\begin{array}{l}\text { Post } \\
\text { Graduation(105) }\end{array}$}} & 20 & 85 & \multirow[t]{2}{*}{$19 \%$} \\
\hline & & \multicolumn{2}{|c|}{ Male-13, Female-07 } & \\
\hline \multicolumn{2}{|c|}{ Occupation } & & & \\
\hline \multicolumn{2}{|c|}{ Students(115) } & 16 & 99 & $13 \%$ \\
\hline
\end{tabular}

\begin{tabular}{|l|c|c|c|}
\hline \multirow{2}{*}{$\begin{array}{l}\text { Graduation(95)+Post } \\
\text { Graduation(20) }\end{array}$} & \multicolumn{2}{|l|}{ Male-10, Female-06 } & \\
\hline Employees(85) & 14 & 71 & $16.4 \%$ \\
\cline { 2 - 3 } & Male-11, Female-03 & \\
\hline Age & Female & male & $12 \%$ \\
\hline $18-24(62)$ & 08 & 54 & $12 \%$ \\
\hline $25-29(32)$ & 06 & 26 & $18.75 \%$ \\
\hline $30-34(54)$ & 08 & 46 & $14.81 \%$ \\
\hline $35-39(26)$ & 04 & 22 & $15.38 \%$ \\
\hline $40-44(15)$ & 03 & 12 & $20 \%$ \\
\hline $45-50(09)$ & 01 & 08 & $11 \%$ \\
\hline Greater than 55(02) & 00 & 02 & $0 \%$ \\
\hline
\end{tabular}

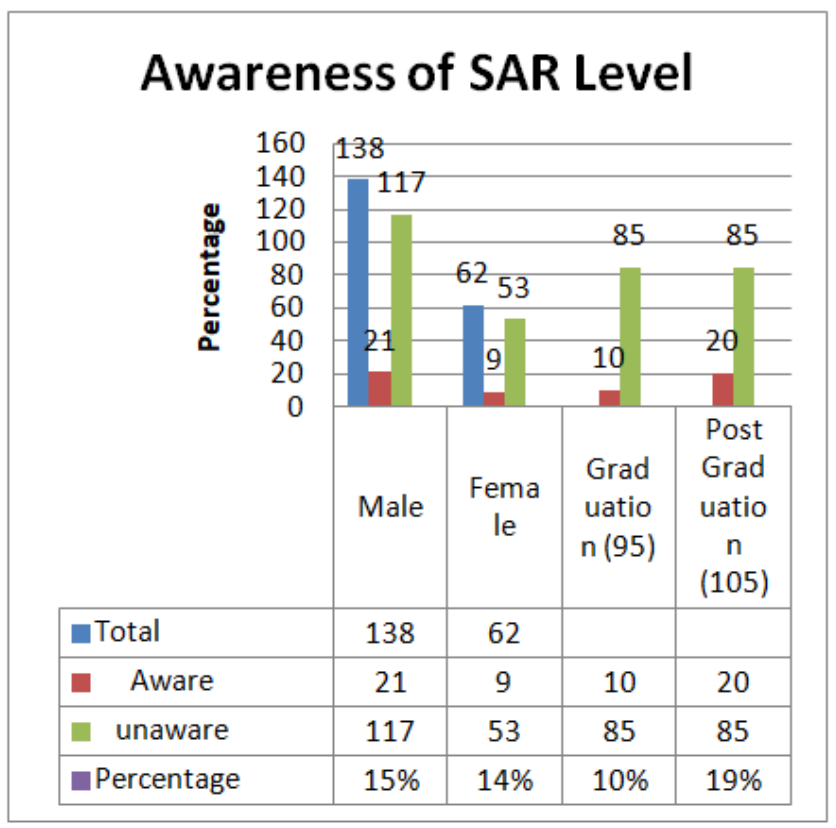

Fig. 4. Analysis of the Head SAR Range

\section{RESEARCH ON SAR REDUCTION \& ADVERSE EFFECTS OF SAR}

Lot of research has been done across the world and many of the techniques and methods are adopted to Reduce the SAR Reduction, but still it is challenge to many of the researchers .Jeong-Haelee et.al[2] designed a Artificial Magnetic Conductor integrated with PIFA to reduce the Specific Absorption Rate. Amirhossein et.al[3]Proposed a Microstrip Patch antenna to reduce Specific Absorption Rate with the help of metal case , Produces $0.52 .0 .25 \mathrm{~W} / \mathrm{Kg}$ on human head at 0.9 and $2.4 \mathrm{Ghz}$ Respectively. P.R.Arul Jenshiya et.al.[4] Proposed antenna with FR-4 Material as Substrate to Reduce the SAR Value $(0.00109 \mathrm{~W} / \mathrm{Kg})$ for $1 \mathrm{~g}$ of tissue. Jalal Khan et.al[5] designed an array of antennas operating in K-band at 28 and $38 \mathrm{Ghz}$,it gives 0.37 nd 1.34 $\mathrm{W} / \mathrm{kg}$ for $5 \mathrm{G}$ mobile handheld Device. PVY Jayasree et.al[12] modeled a human brain in HFSS and Measured the SAR Values on Skin and Brain $(0.95 \mathrm{~W} / \mathrm{Kg}$ and $0.75 \mathrm{~W} / \mathrm{Kg})$ with use of Germanium or Leather as a shield between Mobile antenna and human brain and result taken at different thickness of the shield $(0.1 \mathrm{~cm}$ and $0.2 \mathrm{~cm})$. 


\section{A .Adverse Effects:}

Exposure to EMF from Various sources like Mobile Phones, base stations and high voltage Power lines lead to Adverse health effects. With Increase of SAR Values The Common Biological Effect are eye Irritation and cataracts, Fatigue and exhaustion, Anxiety, Sleep disruption and depression and Serious Biological Effects with increasing of SAR Values are Brain Tumors, Alzheimer's disease ,Parkinson's disease, eye cancer, leukemia, Disturbances in Brain Nervous system it leads to bleed in Brain .

\section{REFERENCES}

1. S Bhagat,Varshney S,Bist SS,Goel D,Mishra S,Jha VK 2016 Effects of auditory function of Chronic exposure to Electromagnetic field for Mobile phones,Ear Nose throat,Pubmed PMID :27551848

2. Jae-gon lee,jeong-Haelee 2017 Integration of PIFA and AMC Structure for Pentaand Mobile Terminals in International Journal of Antennas and Propagation,Hindawai

3. Amirhossein Nazeri,A.Abdolali,M.Mehadi May 20192019 "An Extremely Safe Low-SAR antenna with study of its Electromagnetic Biological effectson human head", Springer

4. P.R.Arul Jenshiya,K.Madhan Kumar and H.RiyazFathima 2019 Evaluation of Specific Absorption Rate of Electromagneti Radiation on human brain-Microstrip Patch Antenna ICT Journal on Communication Technology

5. J Khan,D. Ali Sehrai,U. Ali Sep 2018 Design of Dual band 5G antenna array with SAR Analysis for Future Mobile Handset, Journal of Electrical Engineering \& Technology.

6. Nur Iiham Ishak,Norhudah Seman,Mohammad Ramlee Kamarudin and Noor Asmawathi Samsuri 2017 "Specific Absorption Rate investigation on Multiple Antennas" international Symposium on Antennas and Propagations.

7. Israa H.Ali,Huda I.Hamed and Ali I.Abdalla, 2018 "Design and Comparison of two types of antennas for SAR Calculation in Wireless Applications" Proceedings of International Conference on Advances in Science and Engineering Technology

8. Kumar N and G.Kumar Dec 2009 "Biological effects of cell tower Radiations on Human body "International Symposium on Microwave and optical Technology

9. Bary-El Hamdy, M.Youssef .Umar, Khaled T.Ramdan 2018 Influence of Thermal Wave Emitted by the Cellular Devices on The Human Head,Springer.

10. Prabir Kumar Datta,PVY Jayasree ,Baba VSSNS June 2016 SAR Reduction in the Modeled Human Head for the Mobile Phone using different material shields, Human-Centric Computing and information Sciences

11. V.Bharat Kumar,V.Gopi,,P.V.Y.Jaya sree April 2014 Evaluation of Electromagnetic absorption in Human head from Mobile Phones IOSR Journal of Engineering

12. Raj Gopal B,Raja Sekhar April 2014 SAR assessment on Three Layerd Spherical Human head Model irradiated by Mobile Phone Antenna,Hum-Centric Compute Information

\section{AUTHORS PROFILE}

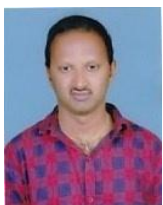

P.A.Kumar, $\mathrm{He}$ is currently working as a Assistant professor of Electronics and Communication Engineering in Avanthi Institute of Engineering and Technology, Visakhapatnam,A.P.. He is currently Pursuing Ph.D degree at the GITAM Deemed to be University, Visakhapatnam, Andhra Pradesh

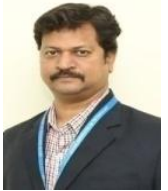

Raghavendra Phani Kumar.Ch, Assistant Professor in the department of Electrical, Electronics and Communication Engineering, GITAM Deemed to be University, Visakhapatnam,A.P. His field of interest includes wireless Communications, EMI/EMC, Antennas. He is having more than 14 years of Experience in teaching 